\title{
Chronopotentiometric method for the assessment of ionophore diffusion coefficients in solvent polymeric membranes
}

\author{
Sándor Bodor • Justin M. Zook • Ernő Lindner • \\ Klára Tóth • Róbert E. Gyurcsányi
}

Published online: 2 September 2008

(C) Springer-Verlag 2008

\section{Erratum to: J Solid State Electrochem}

\section{DOI 10.1007/s10008-008-0614-3}

The original version of this article unfortunately contained a mistake. In the published article, " $\pi$ " should not be superscript in the third term of Eq. 4. The corrected equation is given below.

$\tau_{\mathrm{IL}_{\mathrm{k}}^{\mathrm{n}+}}^{1 / 2} \approx \frac{n F C_{\mathrm{IL}_{\mathrm{k}}^{\mathrm{n}+}} \sqrt{D_{s} \pi}}{21^{\mathrm{o}}\left(1-t_{+}\right)}=\frac{n F C_{\mathrm{IL}_{\mathrm{k}}^{\mathrm{n}+}}}{21^{\mathrm{o}}} \sqrt{\frac{(n+1) \pi D_{\mathrm{IL}_{\mathrm{k}}^{\mathrm{n}+}}}{n\left(1-t_{+}\right)}}$

The online version of the original article can be found at http://dx.doi. org/10.1007/s10008-008-0614-3.

S. Bodor $\cdot$ K. Tóth $\cdot$ R. E. Gyurcsányi $(\bowtie)$

Department of Inorganic and Analytical Chemistry,

Budapest University of Technology and Economics,

Szt. Gellért tér 4,

Budapest 1111, Hungary

e-mail: robertgy@mail.bme.hu

\section{K. Tóth • R. E. Gyurcsányi}

Research Group of Technical Analytical Chemistry of the

Hungarian Academy of Sciences,

Budapest University of Technology and Economics,

Szt. Gellért tér 4,

Budapest 1111, Hungary

J. M. Zook $\cdot$ E. Lindner

Department of Biomedical Engineering,

The University of Memphis,

Memphis, TN 38152, USA 